\title{
Chronic pain in the elderly, associated factors and relation with the level and volume of physical activity
}

\author{
Dor crônica em idosos, fatores associados e relação com o nível e volume de atividade física
}

Fátima Ferretti ${ }^{1}$, Marcia Regina da Silva ${ }^{2}$, Fabiane Pegoraro ${ }^{3}$, Jéssica Elis Baldo ${ }^{3}$, Clodoaldo Antonio De Sá $^{1}$

DOI 10.5935/2595-0118.20190002

\section{ABSTRACT}

BACKGROUND AND OBJECTIVES: Chronic pain is associated with functional limitations in the elderly, negatively affecting the health of this population. The activity and/or physical exercise has been proposed as a non-drug intervention with positive effects in the treatment of chronic pain. Thus, this study aimed to identify the prevalence of chronic pain in the elderly, analyze the factors associated with pain and its relationship with the level and volume of physical activity practice.

METHODS: Quantitative and cross-sectional research with 385 elderly ( $67.3 \%$ women and $32.7 \%$ men) who were evaluated regarding the level and volume of physical activity practice, the presence of chronic diseases, presence and intensity of chronic pain.

RESULTS: The prevalence of chronic pain in the sample was $58.2 \%$ and was associated with the gender and the presence of chronic diseases $(\mathrm{p}<0.001)$. The median pain intensity was higher in sedentary women $(\mathrm{p}=0.005)$, as they presented a lower volume of physical activity practices $(\mathrm{p}<0.001)$.

CONCLUSION: The prevalence of chronic pain among the evaluated elderly is high and associated with the presence of chronic diseases and to gender, being more prevalent among women. Sedentary or insufficiently active elderly women report higher pain intensity than active and very active women. There is poor correlation indicating that the level of physical activity decreases with increasing pain intensity and the number of chronic diseases. Elderly people with chronic pain have significantly lower volumes of physical activity practice than those who do not.

Keywords: Chronic disease, Chronic pain, Elderly, Physical activity.

Fátima Ferretti - Dhttps://orcid.org/0000-0002-0326-2984;

Marcia Regina da Silva - (Dhttps://orcid.org/0000-0002-9930-3102;

Fabiane Pegoraro - (Dhttps://orcid.org/0000-0003-4570-4880;

Jéssica Elis Baldo - (Dhttps://orcid.org/0000-0002-8171-8086;

Clodoaldo Antonio De Sá - (Dhttp://orcid.org/0000-0001-7409-8870.

1. Universidade Comunitária da Regiẫo de Chapecó, Programa de Pós-Graduaçấo Stricto Sensu em Ciências da Saúde, Chapecó, SC, Brasil.

2. Universidade Comunitária da Regiâo de Chapecó, Curso de Fisioterapia, Chapecó, SC, Brasil.

3. Universidade Comunitária da Regiáo de Chapecó, Chapecó, SC, Brasil.

Submitted in May 06, 2018.

Accepted for publication in September 04, 2018.

Conflict of interests: none - Sponsoring sources: none

Correspondence to:

Servidão Anjo da Guarda, no 295-D - Bairro Efapi

89809-900 Chapecó, SC, Brasil.

E-mail: ferrettifisio@yahoo.com.br

(c) Sociedade Brasileira para o Estudo da Dor

\section{RESUMO}

JUSTIFICATIVA E OBJETIVOS: A dor crônica está associada a limitaçôes funcionais em pessoas idosas, afetando negativamente a saúde dessa populaçáo. A atividade e/ou exercício físico tem sido proposto como uma intervenção não farmacológica com efeitos positivos no tratamento da dor crônica. Assim, este estudo objetivou identificar a prevalência de dor crônica em idosos, analisar os fatores associados à dor e sua relação com o nível e volume de prática de atividades físicas.

MÉTODOS: Pesquisa quantitativa e transversal com 385 idosos ( $67,3 \%$ mulheres e $32,7 \%$ homens) que foram avaliados quanto ao nível e volume de prática de atividades físicas, presença de doenças crônicas, presença e intensidade de dor crônica.

RESULTADOS: A prevalência de dor crônica na amostra estudada foi de $58,2 \%$ e foi associada com o sexo e com a presença de doenças crônicas $(\mathrm{p}<0,001)$. A mediana da intensidade da dor foi mais alta em mulheres sedentárias $(\mathrm{p}=0,005)$, assim como elas apresentaram menor volume de prática de atividades físicas $(\mathrm{p}<0,001)$.

CONCLUSÁO: A prevalência de dor crônica entre os idosos avaliados é alta e está associada à presença de doenças crônicas e ao sexo, sendo mais prevalente entre as mulheres. Mulheres idosas sedentárias ou insuficientemente ativas relatam maior intensidade da dor do que as ativas e muito ativas. Há fraca correlaçáo indicando que o nível de atividade física diminui com o aumento da intensidade da dor e o número de doenças crônicas. Idosas com dor crônica apresentam volumes de prática de atividade física significativamente menores do que as que não possuem.

Descritores: Atividade física, Doença crônica, Dor crônica, Idoso.

\section{INTRODUCTION}

Brazil is experiencing a demographic transition characterized by the aging of its population. Data from the Brazilian Institute of Geography and Statistics (IBGE) indicate that the population in the country is approximately 188 million inhabitants, of which 20 million are elderly and projections suggest that in 2030 the elderly will reach 41.5 million Brazilians. This picture has reflected changes in the morbidity and mortality profile, with a higher occurrence of chronic diseases, with a higher prevalence among women ${ }^{1}$.

Among chronic conditions, pain is one of the most common and is associated, in most cases, with musculoskeletal dysfunction and tissue injury, negatively interfering with the health of the elderly $^{2}$. Chronic pain is characterized as persistent events with 
a duration of at least three months, of a biopsychosocial nature, which constitute an important public health problem, whose coping requires a multidisciplinary approach ${ }^{3}$. In general, associated with chronic pathological processes that last for months or years, chronic pain has become the main complaint and cause of functional limitations in the elderly ${ }^{4}$, strongly affecting their independence in the accomplishment of daily tasks.

On the one hand, sedentarism has been associated with an increase in chronic diseases ${ }^{5}$, the practice of mild, moderate or intense physical activity has been positively associated with the positive perception of the health of the elderly ${ }^{6}$. In general, the elderly Brazilian population has been concerned with maintaining a healthier, more active and independent life. The incentive to practice physical activities and/or exercises have been listed as an objective of different public policies and programs in the health area $^{7}$, with the potential to promote a healthy quality of life, especially if they are performed in a systematic way ${ }^{8}$. This study aimed to identify the prevalence of chronic pain in the elderly, analyze the factors associated with pain and its relation with the level and volume of physical activity (PA) practice.

\section{METHODS}

This is a quantitative, analytical and cross-sectional research. The sample consisted of 385 elderly living in the urban area of the city of Chapecó/SC. The sample size was calculated based on a finite population of 13,606 elderly of both genders $^{1}$, considering a $95 \%$ confidence interval and a margin of error of $5 \%$.

The study included individuals of both genders over 60 years old, who had preserved cognitive ability, tested by the Mini-Mental State Examination (MMSE) ${ }^{9}$ (adopted as a criterion score equal to or greater than 24 , corrected for 17 , when education was less than four years).

Elderly who were absent from the home on two visits by the researcher, or who were bedridden, or making use of ancillary devices for locomotion, such as wheelchairs were excluded from the sample.

The researchers who participated in the data collection were trained to use the instruments and conducted a pilot study that involved the collection, extraction, and tabulation of the data. The data collection was organized from the census map of the municipality, which includes 38 tracts. 11 census tracts were randomly selected. The maps of these tracts were printed so that researchers could plan the collection from the streets of each neighborhood. Every two houses, the first one was drawn and when the place was a building, all people over 60 years old were interviewed. Lots and commercial establishments were excluded and, when pulled, moved to the next home - and so on, in every street until reaching the sample. The visits were carried out from June to August of 2016 in all the residences of the tracts and streets drawn. Each researcher recorded the collection done at the elderly's home on the map that was previously received. The research team met every Friday to assess the progress of collections, check the streets covered, enter the data on the worksheet, and plan the following week.
Each elderly in the home was informed about the purpose of the research, its relevance, objectives, methods, expected benefits, potential risks associated with study participation, and how data would be collected and used later. All subjects who agreed to participate in the study signed an Free and Informed Consent Form (FICT).

All participants signed the FICT. Each participant was assessed in relation to their cognitive ability through the MMSE. If the defined score for the inclusion criteria was reached, the participant moved to the next step that included the General Data questionnaire for the Elderly, adapted from Morais ${ }^{10}$, the pain assessment using the visual numeric scale $(\mathrm{VNS})^{11}$ and the Physical Activity Level (PAL) Assessment questionnaire, the International Physical Activity Questionnaire (IPAQ) - short version $^{12}$.

The study followed all the recommendations of Resolution $466 / 2012 / C O N E P / C N S / M S$ and was approved by the Human Research Ethics Committee of the institution under number CAAE n.613611160.0000.0116.

\section{Statistical analysis}

The data was organized and tabulated initially in the Microsoft Excel spreadsheet. The descriptive statistics of the data were initially used. The statistical test of Shapiro-Wilk was used to verify the normality of the data. The measures of factors associated with chronic pain were analyzed by the chisquare test. The Spearman correlation was used to check the correlation between the variables physical activity (PA) volume with the number of chronic diseases and the intensity of pain by gender. The Mann-Whitney U-test was used for the comparison of the median of the pain rating data by PAL of the elderly by gender, and the median of the volume of PA in the elderly with and without chronic pain by gender. The data were analyzed by the Statistical Package for Social Science for Windows - SPSS version 20.0, and the significance level was set at $\mathrm{p}<0.05$.

\section{RESULTS}

Table 1 presents the characterization data of the study sample as age, gender, presence or absence of chronic pain and its intensity.

The presence of chronic pain in the studied sample was $58.2 \%$ and presented a statistically significant association $(\mathrm{p}<0.05)$ with gender and the presence of chronic diseases (Table 2).

Comparison of the median of the pain rating data by PAL among the elderly by gender shows significant results only for women (Table 3).

There was a weak correlation between the PA volume and the number of chronic diseases only for women (M-rs $=-0.168$ $\mathrm{p}=0.007 / \mathrm{H}-\mathrm{rs}=-045 \mathrm{p}=0.615)$ and with pain intensity (M-rs=$0.230 \mathrm{p}=0.001 / \mathrm{H}-\mathrm{rs}=-115 \mathrm{p}=0.198)$.

The comparison of the medians of the PA volume in the elderly with and without chronic pain by gender is shown in table 4 and shows statistically significant results only for women $(\mathrm{p}<0.05)$. 
Table 1. Sample characteristics according to age group, gender, the presence of chronic diseases, number of chronic diseases, chronic pain and its intensity, 2017

\begin{tabular}{lcc}
\hline Variables & Classification & $\mathrm{n}=385(\%)$ \\
\hline Age (years old) & $60-69$ & $175(45.5)$ \\
& $70-79$ & $154(40.0)$ \\
Gender & $\geq 80$ & $56(14.5)$ \\
& Male & $126(32.7)$ \\
Chronic diseases & Female & $259(67.3)$ \\
& Yes & $331(86.0)$ \\
Number of diseases & No & $50(13.0)$ \\
& None & $50(13.0)$ \\
& Up to 3 & $304(79.0)$ \\
Chronic pain (VNS) & 4 or more & $31(8.0)$ \\
& None & $161(41.8)$ \\
& Mild & $40(10.4)$ \\
& Moderate & $109(28.3)$ \\
& Severe & $75(19.5)$ \\
\hline
\end{tabular}

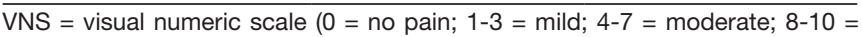
severe).

Table 2. Factors associated with the presence of chronic pain in the elderly, 2017

\begin{tabular}{|c|c|c|c|c|c|}
\hline \multirow[t]{2}{*}{ Variables } & \multicolumn{4}{|c|}{ Presence of chronic pain } & \multirow[t]{2}{*}{$p$-value } \\
\hline & \multicolumn{2}{|c|}{ Yes n (\%) } & \multicolumn{2}{|c|}{ No n (\%) } & \\
\hline \multicolumn{6}{|l|}{ Gender } \\
\hline Male & 57 & $(45.2)$ & 69 & $(54.8)$ & $0.001^{*}$ \\
\hline Female & 167 & $(64.5)$ & 92 & (35.5) & \\
\hline \multicolumn{6}{|l|}{ Age (years old) } \\
\hline 60 to 74 & 157 & (59.5) & 107 & $(40.5)$ & 0.449 \\
\hline 75 or more & 67 & $(55.4)$ & 54 & $(44.6)$ & \\
\hline \multicolumn{6}{|l|}{ Physical activity level } \\
\hline $\begin{array}{l}\text { Sedentary or insuffi- } \\
\text { cient active }\end{array}$ & 112 & (69.9) & 69 & $(38.1)$ & 0.166 \\
\hline Active or very active & 112 & (54.9) & 92 & $(45.1)$ & \\
\hline \multicolumn{6}{|l|}{ Chronic disease } \\
\hline Presence & 208 & (62.1) & 127 & (37.9) & $0.001^{*}$ \\
\hline Absence & 16 & (32.0) & 34 & $(68.0)$ & \\
\hline
\end{tabular}

\section{DISCUSSION}

In this study, there was a predominance of the female gender, represented by $67.3 \%(n=259)$ and 60 to 69 years old in $45.5 \%$ $(n=175)$, which is similar to the data presented by IBGE for this region of Brazil ${ }^{1}$. Literature already shows the feminization of old age, a factor associated with the greater care and awareness that women have regarding their health, which leads them to seek more health services and preventive programs ${ }^{13,14}$.

One of the results of this study was the presence of chronic diseases in $86 \%$ of the sample $(n=331)$. These data are superior to that of the study by Silva and Catão ${ }^{15}$ carried out with 230 elderly in the state of Paraíba, where $69.5 \%$ of the population reported having a chronic disease. Another study with 1,062 elderly showed that $74 \%$ reported the presence of chronic diseases $^{16}$. These data show the high occurrence of these diseases in the elderly. Healthy habits practice physical exercises and access to health care can minimize the suffering that these diseases produce in the elderly's life.

In this sample $58.2 \%(\mathrm{n}=221)$ presented chronic pain and in $28.3 \%(\mathrm{n}=109)$ the intensity was moderate. A research conducted by Dellaroza and Pimenta ${ }^{2}$ with 451 elderly in the state of Paraná, found a prevalence of pain in $51.4 \%$, with $38.43 \%$ reporting moderate intensity, and a study by Landmark et al. ${ }^{17}$ conducted in Norway with 10,249 elderly identified that $35.13 \%$ reported chronic pain of moderate intensity. It was observed in these studies that chronic pain affected more than $50 \%$ of the population. The fact that the elderly live with painful conditions can cause suffering and different intercurrences in the health and quality of life of this population.

In the two elderly groups, with pain and without chronic pain, there was a predominance of active and very active elderly, representing $50 \%(\mathrm{n}=112)$ and $57.1 \%(\mathrm{n}=92)$, respectively. Another important finding in the study was the low sedentary classification in the elderly group with chronic pain, representing $10.7 \%(\mathrm{n}=24)$ and without chronic pain 3.7\% $(\mathrm{n}=6)$. When considering the total sample, the percentage was less than $10 \%$ (7.8\%), with 30 sedentary elderly.

A research of 367 elderly women (60 years old or older) from the cities of Presidente Prudente-SP and Uberaba-MG, who sought to assess the PA level and the anthropometric variables of these

Table 3. Comparison of the medians of the pain scale of the elderly by the level of physical activity and gender, 2017

\begin{tabular}{|c|c|c|c|c|}
\hline $\begin{array}{l}\text { Group } \\
\text { PAL }\end{array}$ & $\begin{array}{c}\text { Male }(n=126) \\
\text { ME (IQR) }\end{array}$ & $\mathrm{p}$-value & $\begin{array}{c}\text { Female }(n=259) \\
\text { ME (IQR) }\end{array}$ & $\mathrm{p}$-value \\
\hline Sedentary or insufficient active & $0(0-4)$ & 0.132 & $5(0-8)$ & $0.005^{\star}$ \\
\hline Active or very active & $2(0-5.5)$ & & $2(0-7)$ & \\
\hline
\end{tabular}

$\mathrm{PAL}=$ physical activity level; $\mathrm{ME}=$ median; IQR = interquartile range; $p=$ Mann-Whitney U-statistic. ${ }^{*}$ Significance level: $p<0.05$.

Table 4. Comparison of the medians of the physical activity volume of the elderly with and without chronic pain by gender, 2017

\begin{tabular}{|c|c|c|c|c|}
\hline $\begin{array}{l}\text { Variables } \\
\text { PAVol (min/week) }\end{array}$ & $\begin{array}{l}\text { Male }(n=126) \\
\text { ME }(I Q R)\end{array}$ & $p$-value & $\begin{array}{c}\text { Female }(n=259) \\
\text { ME }(I Q R)\end{array}$ & $p$-value \\
\hline Presence of chronic pain & $180(77.5-242.5)$ & 0.338 & $130(75-240)$ & $0.001^{*}$ \\
\hline Absence of chronic pain & $150(100-300)$ & & $210(132.5-297.5)$ & \\
\hline
\end{tabular}

$\mathrm{PAVol}(\mathrm{min} /$ week $)=$ physical activity volume in minutes per week. $\mathrm{ME}=$ median; IQR = interquartile range; $\mathrm{p}=$ Mann-Whitney U-statistic. ${ }^{*}$ Significance level: $\mathrm{p}<0.05$. 
women, found a similar result to that of this study (80.4\%) were considered active and participated - on average, 1 year and 3 months - of PA programs ${ }^{18}$.

Other results diverge from the results of this study. A study by Lima et al. ${ }^{19}$ found an index of $66.9 \%$ of sedentary women in 220 senior women. The results of the study by Macedo et al. ${ }^{20}$ with 173 elderly showed that $33.72 \% \quad(n=57)$ of the sample were sedentary. The results found in the study show that the surveyed elderly are less sedentary than the elderly studied in the cited studies.

This divergent reality between the data of this research and those found in the literature, regarding the percentage of actives and sedentary ones, can be explained by the fact that in the municipality where the research was carried out, the place for specific PA practices for the elderly was implanted for more than a decade, called "City of the Elderly". In this place, visitors have access to medical consultation with a geriatrician, supervised PA practice, such as bodybuilding, dance, Pilates, soil and water aerobics, as well as living space, games room, cinema, among other benefits. The place is intended for all the elderly in the municipality and activities are carried out frequently twice a week. This public policy may have encouraged the elderly to remain more active. On the other hand, those with chronic pain of mild and moderate intensity, seek in physical exercise, the minimization of painful conditions, especially those resulting from postural alterations.

On the other hand, when the intensity of chronic pain is high, it becomes one of the main factors limiting the performance of PA in the elderly ${ }^{7}$. Leijon et al. ${ }^{21}$ when researching 1,358 patients enrolled in primary health care settings in Sweden, observed that pain was the most common reason for non-adherence to the practice of PA among older patients.

A study in Germany ${ }^{22}$ that analyzed the barriers to PA in 1,937 elderly with a mean age of 77 years old, observed that the three most cited barriers were poor health $(57.7 \%)$, lack of company $(43.0 \%)$ and lack of interest (36.7\%). Ensuring an active life, regardless of whether or not he/she has pain, can minimize painful conditions. Preventive programs that create mechanisms of adhesion and stimulation to the PA practice need to be strengthened ${ }^{23}$.

The comparison of the PA level with the intensity of pain showed that sedentary or insufficiently active old women presented higher pain intensity than the active and very active ones. The results of the correlation between the variables indicate that the PA volume decreases with the increased pain intensity and the number of chronic diseases for women, although the correlation was considered weak (below -0.3) ${ }^{24}$.

Another fact observed in the study was related to the PA volume in the elderly with or without chronic pain. This aspect was observed in women, where the PA volume is significantly lower in those with chronic pain.

A study by Sawatzky et al..$^{25}$ examined PA as a mediator of the impact of chronic conditions in the elderly in Canada. The authors found that the elderly with chronic conditions are less likely to engage in leisure PA of at least 1,000 Kcal per week. This association partially explained some negative consequences of chronic conditions, including limitations of mobility, pain and emotional problems.

Another study ${ }^{17}$ conducted in Norway with 10,249 elderly over 65 years old identified that increased frequency, duration, and intensity of recreational exercise was associated with lower chronic pain. Elderly who exercise at least two to three times a week have a $27 \%$ lower prevalence of chronic pain compared to those who do not practice physical exercises, and the associations were stronger among women than in men. Therefore, even with pain, physical exercise is effective, if planned according to the specificities of each clinical picture. The increase of chronic diseases during aging is a factor that reduces the PA level among the elderly ${ }^{26}$. A study by Lopes et al. ${ }^{7}$ stated that the advancement of age might be accompanied by a higher number of chronic diseases, which has limited the PA practice.

The decrease in the PA practice in the elderly with limitations or chronic diseases may be associated with the fear that PA can increase painful condition or increase the onset of other lesions. A study by Larsson et al. ${ }^{27}$ analyzed the influence of pain and kinesophobia characteristics (excessive fear of injury or re-injury) as predictors of failure to perform PA in 1,141 elderly with chronic self-reported pain. The study revealed that the PA level was significantly lower among the elderly with chronic pain and significantly associated with kinesophobia.

A study carried out in Brazil, by Silva, Abreu and Suassuna ${ }^{28}$ with 30 elderly women with chronic pain, who sought to identify the occurrence of kinesophobia, observed a presence of $80 \%$ of them experiencing this condition. There was a moderate significant correlation between physical performance and kinesophobia $(r=541 ; p=0.002)$, revealing that the high incidence of kinesophobia in the elderly assessed compromised their physical performance.

Encouraging a healthy lifestyle with regular PA practices reduces the risk of developing chronic diseases in this population ${ }^{29}$. The promotion of PA associated with better living conditions can positively impact the quality of life of the general population. Within this context, the health team must plan health actions not only with a view to treating the clinical conditions of this phase of life, but also to carry out interventions aimed at preventing, maintaining and promoting the health and functional independence of the elderly to enjoy life with longevity.

\section{CONCLUSION}

The presence of chronic pain is associated with a higher number of chronic diseases, by gender (women) and sedentary lifestyle. Sedentary or insufficiently active elderly women report greater intensity of pain when compared to active and very active. There was also a weak negative, and statistically significant correlation between the PA volume practiced with the intensity of pain and the number of chronic diseases in elderly women, and the PA level decreased with increasing pain intensity and the number of chronic diseases. Regarding the PA practice volume, the study identified that elderly women with chronic pain have significantly lower volumes of PA practice than those who do not have chronic pain. 


\section{REFERENCES}

1. IBGE - Instituto Brasileiro de Geografia e Estatística. Distribuiçấo da população por sexo, segundo os grupos de idade Brasil. Rio de Janeiro: IBGE; 2010.

2. Dellaroza MS, Pimenta CA. Impacto da dor crônica nas atividades de vida diária de idosos da comunidade. Ciênc Cuid Saude. 2012;11(Suppl):235-42.

3. dos Santos FA, de Souza JB, Antes DL, d'Orsi E. Prevalence of chronic pain and its Association with the sociodemographic situation and physical activity in leisure of elderly in Florianópolis, Santa Catarina: population-based study. Rev Bras Epidemiol. 2015;18(1):234-47. English, Portuguese.

4. Dellaroza MS, Pimenta CA, Duarte YA, Lebrão ML. [Chronic pain among elderly residents in Săo Paulo, Brazil: prevalence, characteristics, and association with functional capacity and mobility (SABE Study)]. Cad. Saude Piblica.2013;29(2):325-34. Portuguese.

5. Lee IM, Shiroma EJ, Lobelo F, Puska P, Blair SN, Katzmarzyk PT. Effect of physical inactivity on major non-communicable diseases worldwide: an analysis of burden of disease and life expectancy. Lancet. 2012;380(9838):219-29.

6. Cho SI, An DH. Effects of a fall prevention exercise program on muscle strength and balance of the old-old elderly. J Phys Ther Sci. 2014;26(11):1771-4.

7. Lopes MA, Krug RR, Bonetti A, Mazo GZ. Barreiras que influenciaram a não adoção de atividade física por longevas. Rev Bras Ciênc Esporte. 2016;38(1):76-83.

8. Binotto MA, Tassa KO. Atividade física em idosos: uma revisão sistemática baseada no International Physical Activity Questionnaire (IPAQ). Estud Interdiscip Envelhec. 2014;19(1):249-64.

9. Crum RM, Anthony JC, Bassett SS, Folstein MF. Population-based norms for the Mini-Mental State Examination by age and educational level. JAMA. 1993;269(18):2386-91.

10. Morais EP. Envelhecimento no meio rural: condiçôes de vida, saúde e apoio aos idosos mais velhos de Encruzilhada do Sul-RS. (Tese) Ribeirão Preto: Universidade de São Paulo, Escola de Enfermagem de Ribeirão Preto, Doutorado em Enfermagem; 2007.

11. Ciena AP, Gatto R, Pacini VC, Picanço VV, Magno IM, Loth EA. Influência da intensidade da dor sobre as respostas nas escalas unidimensionais de mensuraçáo da dor em uma populaçấo de idosos e de adultos jovens. Semina: Ciências Biológicas e da Saúde. 2008;29(2):201-12.

12. Matsudo SM, Araújo T, Matsudo V, Andrade D, Andrade E, Oliveira LC, et al. Questionário internacional de atividade física (IPAQ): estudo de validade e reprodutibilidade no Brasil. Revista Brasileira de Atividade Física \& Saúde. 2001;6(2):5-18.

13. Victor JF, Ximenes LB, Almeida PC, Vasconcelos FF. Perfil sociodemográfico e clínico de idosos atendidos em Unidade Básica de Saúde da Família. Acta Paul Enferm. 2009;22(1):49-54.
14. Gomes KV, Zazá DC. Motivos de adesão à prática de atividade física em idosas. Revista Brasileira de Atividade Física \& Saúde. 2009;14(2):132-8.

15. Silva $\mathrm{AD}$, Catâo $\mathrm{MH}$. Doenças sistêmicas em idosos nẫo institucionalizados. HU Rev 2012;37(3):299-303

16. Benedetti TR, Mazo GZ, Borges LJ. Condiçôes de saúde e nível de atividade física em idosos participantes e năo participantes de grupos de convivência de Florianópolis. Ciênc Saúde Coletiva. 2012;17(8):2087-93.

17. Landmark T, Romundstad P, Borchgrevink PC, Kaasa S, Dale O. Associations between recreational exercise and chronic pain in the general population: evidence from the HUNT 3 study. Pain. 2011;152(10):2241-7.

18. Paulo TR, Gomes IC, Santos VR, Christofaro DG, Castellano SM, Freitas Júnior IF. Atividade física e estado nutricional: fator de proteção para doenças crônicas não transmissíveis (DCNT) em idosas? Rev Bras Promoç Saúde. 2014;27(4):527-32.

19. Lima AP, Lini EV, Tomicki C, Dellani MP, Portella MR, Doring M. Fatores associado à atividade física em idosos de Estaçáo, Rio Grande do Sul: estudo de base populacional. Rev Bras Ativ Fis Saúde. 2015;20(6):618-22.

20. Macedo RM, Oliveira MR, Cilião MR, Prosdócimo AC, Macedo AC, França D, et al. Nível de atividade física de idosos participantes de um programa de prevençáo de doença cardiovascular. ASSOBRAFIR Ciência. 2015;6(3):11-20.

21. Leijon ME, Faskunger J, Bendtsen P, Festin K, Nilsen P. Who is not adhering to physical activity referrals, and why? Scand J Prim Health Care. 2011;29(4):234-40.

22. Moschny A, Platen P, Klaassen-Mielke R, Trampisch U, Hinrichs T. Barriers to physical activity in older adults in Germany: a cross-sectional study. Int J Behav Nutr Phys Act. 2011;8(121):1-10.

23. Fernandes BL. Atividade Física no processo de envelhecimento. Rev Portal Divulg. 2014;4(40):43-8.

24. Callegari-Jacques SM. Bioestatística: princípios e aplicaçôes. Porto Alegre: Artmed 2003.

25. Sawatzky R, Liu-Ambrose T, Miller WC, Marra CA. Physical activity as a mediator of the impact of chronic conditions on quality of life in older adults. Health Qual Life Outcomes. 2007;5(68):1-11.

26. Coelho CF, Burini RB. Atividade física para prevençáo e tratamento das doenças crônicas năo transmissíveis e da incapacidade funcional. Rev Nutr. 2009;22(6):937-46.

27. Larsson C, Ekval Hansson E, Sundquist K, Jakobsson U. Impact of pain characteristics and fear-avoidance beliefs on physical activity levels among older adults with chronic pain: a population-based, longitudinal study. BMC Geriatr. 2016;16(1):2-8.

28. Silva NS, Abreu SS, Suassuna PD. Ocorrência de cinesiofobia e fatores associados em idosas com dor crônica musculoesquelética: um estudo piloto. Rev Dor. 2016;17(3):188-91.

29. Valério MP, Ramos LR. Promoção de atividade física à populaçáo idosa: revisando possibilidades. Rev Didática Sistêmica. 2013;15(2):155-73. 